\title{
Rare and Atypical Findings in Smith-Magenis Syndrome: A Case Report
}

\author{
Nadir ve Atipik Bulgularla Seyreden Bir Smith-Magenis Sendromu Vakası
}

\author{
Aysel Kalaycı Yiğin, (D) M. Tarık Alay, (D) Mehmet Seven \\ İstanbul Üniversitesi-Cerrahpasa, Cerrahpaşa Tıp Fakültesi, Tıbbi Genetik AD.
}

\begin{abstract}
Smith-Magenis syndrome is a complex sporadically occurring neurodevelopmental disorder affecting many organ systems of the body, which is frequently observed 1/15.000-25.000. Haploinsufficiency caused by the RAI-1 gene at point $17 p 11.2$ are responsible for the clinical manifestations in most of the patients. This syndrome has characterized by distinct craniofacial face appearance, delayed speech and speech difficulty, moderate to severe intellectual disability, behavioral problems and sleep disturbances. Particularly, behavioral problems and sleep disturbances are well defined and almost occur in every patient, gives an important clue about the diagnosis of Smith-Magenis syndrome if accompanied by dysmorphic features. In this study, we present a case with Smith-Magenis syndrome, which is followed by rare, non-typical findings and diagnosed by chromosomal microarray analysis.

ÖZET

Smith-Magenis sendromu 1/15.000-25.000 sikllkta gözlemlenen ve birçok sistemi tutan, genellikle sporadik olarak ortaya çıkan, kompleks nöro-gelişsimsel bir bozukluktur. Hastaların çoğunda görülen klinik bulgulardan, 17p11.2 bölgesinde yer alan Retinoic acid-induced (RAI-1) geninin yol açtığ l haployetersizlik sorumludur. Bu sendromda; kendine özgü kraniofasial görünüm, konuşmada gecikme ve konuşma güçlügüu, orta/ciddi düzeyde zekâ geriliği, davranış problemleri ve uyku bozukluğu bulunur. Özellikle uyku bozukluklar ve davranıs problemleri iyi tanımlanmış olup, neredeyse her hastada gözlenir ve dismorfik bulguların eșlik etmesi durumunda Smith-Magenis sendromu hakkinda önemli bir ipucu verir. Bu makalede, nadir, tipik olmayan bulgularla seyreden ve kromozomal mikrodizin analizi ile tanı konulan Smith-Magenis sendromlu bir olgu sunulacaktır.
\end{abstract}

Key Words:

Smith-Magenis

Syndrome,

Micropenis,

Undescended testis,

RAI1 gene,

Microarray analysis.

Anahtar Kelimeler:

Smith-Magenis

Sendromu,

Mikropenis,

Inmemiş testis,

RAI-1 geni,

Mikrodizin analizi.

\section{GİRIŞ}

Smith Magenis sendromu (SMS) 1/15.000-25.000 sıklıkta gözlemlenen, birçok organ ve sistemi tutan, genellikle sporadik görülen, kompleks genetik bir bozukluktur. Hastaların çoğunda ortaya çıkan değişik klinik bulgulardan $17 \mathrm{p} 11.2$ bölgesinde yer alan Retinoic acid-induced (RAI-1) geninde meydana gelen haployetersizlik sorumlu tutulmaktadır (1-3). SMS'unun klinik bulguları arasında kranio-fasial bulgular ön plandadır. Çoğunlukla yüz görünümü kendine özgü olup, konuşmada gecikme ve konuşma güçlüğü, orta/ciddi düzeyde zekâ geriliği, davranış problemleri ve uyku bozuklukları bulunur. Başlıca kranio-fasial bulgular; brakisefali, frontal bossing, hipertelorizm, sinofiris, upslanting palpebral fissur, orta hat hipoplazisi, çadır dudak, ileri yaşlarda relatif prognatiye dönüşen mikrognatidir. Dismorfik bulguların yanı sıra kardiak ve renal anomalilere de rastlanmaktadır $(1,2)$. Ancak bu vakalarda literatürde bugüne kadar değişik ürogenital anomaliler bildirilirken mikropenisten sadece birkaç vakada söz edilmiştir. SMS'da gelişim ve davranış sorunlarına da oldukça sık rastlanır. En sik gözlenilen davranış problemleri; kendi kendilerine zarar verme, dikkat eksikliği ve hiperaktivite, vücut orifislerine yabanc1 cisim sokma, el ve ayak tırnaklarını yeme, aşırı gerginlik ve sinirlilik halleri, spazmodik olarak üst vücut bölgelerini sıkma ve kendi kendilerini kucaklama gibi stereotipik hareketlerdir (1). Neredeyse tüm hastalarda sirkadiyen ritm tersine dönmüştür. $\mathrm{Bu}$ yüzden hastalar gece yerine gündüz saatlerinde uyurlar. Uyku bozukluğunun melatonin üretiminde, salınımında veya metabolizmasında bozulma ile ilgili olduğu düşünülmektedir (4). Stereotipik hareketlerin, aşırı gerginlik ve sinirlilik hallerinin diürnal ritm bozukluğundan kaynaklanabileceği, bu davranış tipinin SMS'un karekteristik davranış bozuklukları arasında yer aldığı belirtilmiştir (5-7). Bu çalışmada kromozomal mikrodizin analizi ile tanı konulan, mikropenis ve inmemiş testis gibi nadir görülen bulguların eşlik ettiği Smith-Magenis sendromlu bir olgu sunulacaktır.

\section{OLGU SUNUMU}

Gündüzleri uyuyup geceleri uyumama, strabismus, obezite ve penisin çok küçük olması gibi yakınmalarla polikliniğimize başvuran 3 yaşında erkek hastanın, anne baba arasında akrabalık olmadığı, prenatal USG'de oligohidroamnioz saptandığı, hastanın teyzesinde insomnia olduğu ifade edildi. Diğer akrabalarında doğumsal anomali ve kalıtsal bir hastalık mevcut değildi. Hastanın; gebeliğin 38. haftasında 3200 gram ağırlığında hastanede sezaryanla dünyaya geldiği, 1-5. dakika Apgar skorunun 9 ve 10 olduğu, 3 aylıkken başını tuttuğu, 9 aylıkken desteksiz oturmaya 


\section{Kalaycı Yiğin at al.}

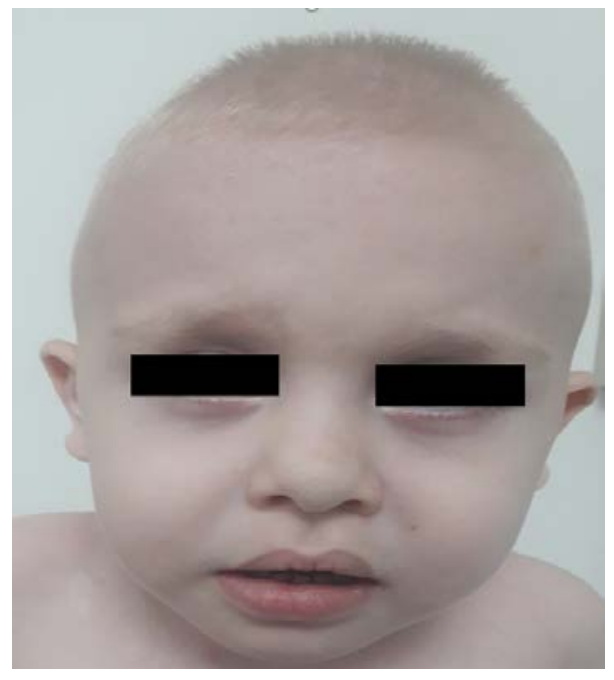

Resim 1: Hastanın dismorfik yüz görünümü

başladığı, 18 aylıkken yürüdüğü belirtildi. Olgumuz 3 yaşını bitirmiş olmasına rağmen, hala konuşamıyordu. Antropometrik ölçümlerde boyu; 88cm (3-10p), kilosu; $12 \mathrm{~kg}$ (3-10p) ve baş çevresi; 48cm (25-50p) olarak ölçüldü. Hastanın uyku ritminin tersine döndüğü, gündüzleri uyuklayıp geceleri ise tam tersine çok hareketli olduğu, zaman zaman öfke nöbetleri geçirdiği, bu nöbetler esnasında kendi elini, kolunu ısırıp vücuduna zarar verdiği ifade edildi.

Hastanın fizik muayenesinde; sarı seyrek saçlar, yüksek frontal saç çizgisi, dikdörtgen yüz, antevert nostril, bulboz burun, brakisefali, supraorbital kemer silikliği, strabismus, uzun filtrum, çadır üst dudak, aşağı bakan dudak kenarları, küçük ağız ve yüzde orta hat hipoplazisi saptandı (Resim 1). Bu bulgulara santral obezite eşlik ediyordu. Hastanın bilateral testis muayenesinde testisler skrotumda palpe edilemedi ve mikropenis mevcuttu. Hastanın nörolojik muayenesinde; infantil dönemde hipotoni saptanmıştı. Bilateral derin tendon refleksleri alınıyordu. İşitme ve görme testleri normaldi. Ekokardiografi ve tüm batın ultrasonografisinde patolojik bir özellik saptanmadi. Skrotal USG de her iki testis inguinal kanalda gözlendi. Kranial MR'da corpus callosumda incelme mevcuttu. 1 yaş 5 aylıkken yapılan Denver gelişim testinde; ince motor gelişimi 7 ay, kaba motor gelişimi 10 ay, dil gelişimi 8 ay ve kişisel-sosyal gelişimi 7 ay olarak bulundu. Karyotip analizi normaldi. Klinik bulgularla Smith-Magenis sendromu düşünülerek mikrodizin analizi yapıldı. 17.kromozomun k1sa kolu üzerinde (17p11.2) bölgesinde yer alan $R A I-1$ geninde $3,8 \mathrm{~Kb}$ l1k heterozigot bir delesyon (chr:17:16,783,64520,392,074 hg19) tespit edilerek tanı doğrulandı (Şekil 1).

$\mathrm{Bu}$ makalenin yayınlanması için hastadan bilgilendirilmiş onam alındı.

\section{TARTISYMA}

Smith Magenis sendromu (SMS); pek çok sistemi tutan kongenital anomaliler ve mental retardasyonla seyreden genetik bir hastalıktır. SMS'un nedeni, genellikle 17.kromozomda Smith Magenis kritik bölgesinde yer alan Retinoic acid-induced geninde (RAI-1) oluşan bir mutasyondur. Bu mutasyon baskın etkili heterozigot delesyon olup, 17p11.2'e bölgesinde lokalizedir. Klinik bulgulardan delesyonun yol açtığ haployetersizlik sorumlu tutulmaktadır (1-3).

SMS'da kraniofasial bulgular, iskelet sistemi deformiteleri, büyüme bozuklukları, nörogelişimsel ve davranışsal problemler, işitme kaybı, ses kalınlaşması, hiperakuzi gibi semptomlar sik görülmektedir. $\mathrm{Bu}$ hastalarda görülen kardiak defektler, immun yetersizlik, tiroid problemleri, ön kol bozuklukları, retina ayrılması, yarık dudak-damak, üriner ve renal anomaliler ise nadir bulgular arasında yer alır. SMS'de genital anomaliler sık olmasa da erkeklerde inmemiş testis ve gelişmemiş skrotum, kadınlarda hipoplazik uterus ve gelişmemiş servikse rastlanabilmektedir (8), ancak mikropenis sadece birkaç vakada bildilmiştir.

Önceki yıllarda klinik bulgular SMS'i düşündürdüğünde yüksek rezolusyonlu $\mathrm{G}$ bantlama (HRB) ve SMS'e spesifik olarak tasarlanan problarla Floresan In Situ Hibridizasyon (FISH) yapılmaktayd. Günümüzde tanı testi olarak ilk aşamada mikrodizin analizi önerilmektedir. Yüksek rezolusyonlu G bantlama ve FISH'in tanı koyma oranının mikrodizin analizine göre düşük olması nedeniyle SMS'in rutin tanısında önemini kaybettiği belirtilmektedir. $\mathrm{Bu}$ nedenle hastalığın tanısında artık FISH yerine mikrodizin analizi tercih edilmektedir (8). Mikrodizin analizi, FISH ve kromozom analizi birlikte yapıldığında SMS hastalarında tanı koyma oranı \%95'e yükselmektedir (9). İntragenik delesyon/insersiyon, missense, nonsense ve kesim bölgesi mutasyonlarından kaynaklanan ve bu nedenle mikrodizin analizi ile tanı konulamayan vakalarda ise DNA dizileme yöntemi kullanılmaktadir (8).

Smith Magenis Sendromunun ayırıcı tanısında; ilk

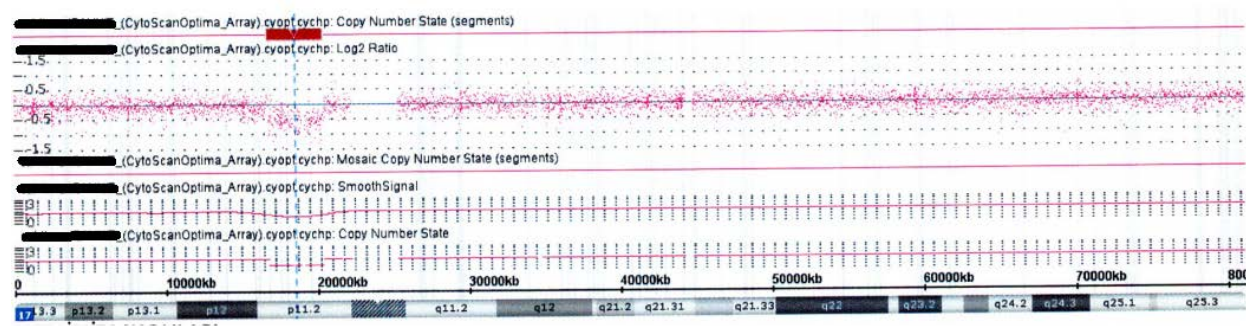

Şekil 1: Hastanın delesyon bölgesinin mikrodizin analiz görüntüsü 
planda Prader-Wili Sendromu, Down Sendromu, Velokardiofasial Sendrom, Fragile-X Sendromu, Kleefstra Sendromu, Sotos Sendromu, 1p36 Delesyon Sendromu, Williams Sendromu akla gelmelidir $(9,10)$. İnfantil dönemde hipotoni, yukarı çekik göz aksı ve düzleşmiş ortayüz gibi bulgularla Down sendromu düşünülmekte ve kromozom analiziyle ekarte edilebilmektedir. Keza infantil hipotoni, letarji, beslenme, obezite ve uyku sorunlarıyla Prader-Willi sendromu, konuşmanın gecikmesi ve kardiyak anomalilerle 22q11.2 delesyon sendromu (DiGeorge/velo-kardiyo-facial sendrom), otistik bulgular ve davranış bozukluklarıyla Frajil-X sendromu akla gelmektedir. $\mathrm{Bu}$ sendromlar bölgeye spesifik FISH ve fragman analiziyle ekarte edilebilmektedir. Ayrıca hastalarda sıkça görülen davranış kusuru nedeniyle, dikkat eksikliğihiperaktivite bozukluğu ve obsesif kompulsif bozukluk ile otizm spektrum bozukluğu olarak da değerlendirilebilmekte, ancak karakteristik dismorfik yüz bulguları, diğer klinik ve laboratuar bulgularıyla tanıya gidilebilmektedir (9). SMS'nin diğer dismorfik bulgularla seyreden hastalıklardan ayrımında yer alan başlica bulgulardan birisi de hastaların hemen hemen tamamında görülen sirkadiyen ritim bozukluğudur. Sirkadyen ritmin bozulmasında suprakiazmatik nukleus tarafından salınan melatonin seviyelerindeki değişimin etkili olduğu düşünülmektedir. Yapılan araştırmalar melatonin seviyelerindeki değişimlerin yalnızca diurnal ritmi değil aynı zamanda hastalıkta gözlemlenen öğrenme güçlüğü, azalmış farkındalık seviyeleri ve davranış bozuklukları üzerinde de etkili olduğunu göstermektedir (9).

Literatürde Brakidaktili-Mental Retardasyon (BDMR) sendromunda RAI-1 gen ekspresyonunda azalma meydana geldiği gösterilmiş, hastalığın 2q37 bölgesinde oluşan delesyon ya da Histon deasetilaz 4 (HDAC4) genindeki mutasyonlardan kaynaklanmış olabileceği bildirilmiştir. SMS ve BDMR'nin her ikisinde de obezite, kendine zarar verme ve uyku bozukluğu gibi benzer bulgular gözlenmesi, 2q37 delesyonlu birçok hastaya SMS tanısı konulmasına neden olmuştur. Ayırıcı tanı ancak mikrodizin analiziyle mümkün olabilmiştir (11).

SMS'nin delesyon bölgesinde TNFRS13B, FLCN, TOM1L2 ve SREBF1 genleri de yer almaktadır. $\mathrm{Bu}$ genlerden TNFRS13B T hücre bağımsız immun yanıtı ve $B$ hücrelerinin tolerans düzeylerini kontrol eder. FLCN geni, tümör baskılayıcı bir gen olup, mutasyonu Birth-Hogg-Dube sendromlu hastalarda gözlemlenmiştir. TOM1L2 geni defektlerinin farelerde enfeksiyon ve tümör gelişimine yatkınlıktan sorumlu olduğu gösterilmiş, insandaki etkisi bilinmemektedir (12). SREBF1 ile ilgili çalışmalarda, bu genin osteoblastlarda ve iskelet kas dokusunda eksprese edildiği ve SREBF1 ekspresyonundaki artışın SREBF1 protein miktarında artışa yol açtığı gösterilmiştir. $\mathrm{Bu}$ artışın kemik mineralizasyonunda artışa ve myogenezde azalmaya yol açtığı belirtilmiştir (13). SMS'le ilgili gen bölgesinde yer almakla birlikte, bu genlerdeki değişikliklerin SMS'in kliniği ile henüz doğrudan bir ilişkisi kurulamamıştır.

Sonuç olarak; mevcut olguda, dismorfik yüz bulguları, konuşma güçlüğü, davranış kusuru ve uyku ritm bozukluğuyla SMS düşünülmüş ve mikrodizin analiziyle tanı doğrulanmıştır. Mikropenis varlığının SMS tanısında göz önünde bulundurulması gereken nadir bir klinik bulgu olduğu, yaşla korele olmayan bu bulgunun SMS'in klinik tanısında yer alıp almayacağı konusunda daha fazla veriye ihtiyaç duyulduğu, yeni vaka bildirimleri ile bu bulgunun desteklenmesi halinde hastalığın tanısında kullanılan algoritmalar arasına dahil edilebileceği düşünülmektedir.

ÇIKAR ÇATIŞMASI

Tüm yazarlar çıkar çatışması olmadığını beyan eder.

\section{KAYNAKLAR}

1. Elsea SH, Girirajan S. Smith-Magenis syndrome. European Journal of Human Genetics. 2008; 16(4), $412-421$.

2. Falco M, Amabile S, Acquaviva F. RAI1 gene mutations: mechanisms of Smith-Magenis syndrome. Appl Clin Genet. 2017; 10:85-94.

3. Greenberg F, Guzzetta V, Montes de Oca-Luna R, Magenis RE, Smith AC, Richter SF et al. Molecular analysis of the Smith-Magenis syndrome: a possible contiguous-gene syndrome associated with del(17)(p11.2). Am J Hum Genet. 1991; 49(6):1207-18.

4. Chen L, Mullegama SV, Alaimo JT, Elsea SH. Smith-Magenis syndrome and its circadian influence on development, behavior, and obesity - own experience. Dev Period Med. 2015; 19(2):149-56. Review.

5. Smith AC, Dykens E, Greenberg F. Sleep disturbance in Smith-Magenis syndrome (del 17 p11.2). Am J Med Genet. 1998; 81(2):186191.

6. Vlangos CN, Yim DK, Elsea SH. Refinement of the Smith-Magenis syndrome critical region to approximately 950kb and assessment of 17p11.2 deletions. Are all deletions created equally? Mol Genet Metab. 2003; 79(2):134-41.

7. Boudreau EA, Johnson KP, Jackman AR, Blancato J, Huizing M, Bendavid C et al. Review of disrupted sleep patterns in Smith-Magenis syndrome and normal melatonin secretion in a patient with an atypical interstitial 17p11.2 deletion. Am J Med Genet A. 2009; 149A (7):1382-91.

8. Smith ACM, Boyd KE, Brennan C, Charles J, Elsea SH, Finucane BM, Foster R, Gropman A, Girirajan S, Haas-Givler B. Smith-Magenis Syndrome. 2001 Oct 22 (updated 2019 Sep 5). In: Adam MP, Ardinger HH, Pagon RA, Wallace SE, Bean LJH, Stephens K, Amemiya A, editors. GeneReviews ${ }^{\circledR}$ (Internet). Seattle (WA): University of Washington, Seattle; 1993-2019.

9. Nijim Y, Adawi A, Bisharat B, Bowirrat A. First Case Report of Smith-Magenis Syndrome (SMS) Among the Arab Community in Nazareth: View and Overview. Medicine (Baltimore). 2016 Jan;95(3):e2362.

10. Gropman, A. L., Elsea, S., Duncan, W. C., \& Smith, A. C. (2007). New developments in Smith-Magenis syndrome (del 17p11.2). Current Opinion in Neurology, 20(2), 125-134. 


\section{Kalaycı Yiğin at al.}

11. Doherty ES, Lacbawan FL. 2q37 Microdeletion Syndrome. 2007 May 3 (Updated 2013 Jan 31). In: Adam MP, Ardinger HH, Pagon RA, et al., editors. GeneReviews ${ }^{\circledR}$ (Internet). Seattle (WA): University of Washington, Seattle; 1993-2019.

12. Perkins T, Rosenberg JM, Le Coz C, et al. Smith-Magenis Syndrome Patients Often Display Antibody Deficiency but Not Other Immune Pathologies. J Allergy Clin Immunol Pract. 2017;5(5):1344-1350.e3.

13. Medina-Gomez C, Kemp JP, Dimou NL, Kreiner E, Chesi A, Zemel BS et al. Bivariate genome-wide association meta-analysis of pediatric musculoskeletal traits reveals pleiotropic effects at the SREBF1/TOM1L2 locus. Nat Commun. 2017; 25;8(1):121. 